\title{
Not Even to Know That You Do Not Know: Cicero and the "Theatricality" of the New Academy
}

Soumick De

\begin{abstract}
The relation between philosophy and theatre has mostly been an ambiguous one, frequently informed with a certain playful irony. Plato's aversion to include the tragic poets in his Republic, which itself remains a philosophical work written in the dramatic form of dialogues, testifies to this traditional ambiguity. It is well known that in this tradition of philosophic dialogues, the name which perhaps immediately follows Plato is that of Marcus Tullius Cicero. This paper would examine certain Ciceronian dialogues in order to argue that a certain theatricality was also prominent in Cicero's thinking, which makes it distinct not only from other philosophical schools of his time but also from Socratic dialogues. The paper would try to argue that this theatricality was expressed not through irony but a process of masking philosophical presentations. At the same time, to such a theatrical gesture par excellence as that of masking was added the art of rhetoric to present such philosophical enunciations to an 'audience' in order to persuade them of the practical functions of philosophy. It is this public application of a private and leisurely practice of philosophy, which this paper would discuss through an examination of the style of Ciceronian dialogues and the nature of skeptic philosophy that Cicero's New Academy championed.
\end{abstract}

Keywords: Cicero, Socrates, irony, skepticism

7 he tradition of philosophical dialogues is not new to us. In its unique way of expressing concerns about meanings of life and death, about the order of things and the nature of beauty, about what constitutes truth, and about what is ethical and what is political, the technique of employing dialogues goes as far back as Socrates. In fact, to engage in dialogues was the Socratic method par excellence. In Socrates we have the apparent duality of silence and dialogue always at work. The anonymous

(C) 2015 Soumick De

http://www.kritike.org/journal/issue 17/de december2015.pdf

ISSN 1908-7330

(cc) $\mathrm{BY}-\mathrm{NC}-\mathrm{ND}$ 
figure of the philosopher would on one hand stand in silence, alone in the midst of the worldly cacophony, separated from it as an absolute and independent personality in his contemplative repose. At the same time we have the "essential impact of such an original personality upon the race and its relation to the race (which) fulfil themselves partly in a communication of life and spirit, partly in a release of the individual's locked-up powers." ${ }^{1}$ It is the dialogues, which carry the secret force of this impact as it melts the finite boundaries of existence and allows us to stare into the nothingness of the abyss beyond. Thus, at least this much can be said, that the art of engaging in dialogues has a profound relation to Philosophy since around its inception. As a matter of fact, the Greek word dia-legein from which the idea of dialogue is conceived belongs to a family of other Greek words like dialegesthai and dialectike, the latter being the source for the concept of dialects or the art (techne) of discourse.

What this relation perhaps also indicates, but is quite infrequently dealt with within philosophical discourses, is the constant but difficult association of philosophy with theatre. If the discursive practice of dialogues in philosophy opens up the method of dialectics, then it also provides us with a way of understanding and critiquing the nature of this philosophical theatre. Conversely, theatre in this philosophic sense or more precisely the idea of theatre will always be then subjected to this 'movement' within philosophy, which is identical with the dialectical movement. Thus, like dialectic which cannot function without certain fundamental but contrary propositions, which the ancients called axioma, the movement inherent to a notion of theatre cannot operate without the fundamental but oppositional proposition of an 'actor' and a 'spectator.' When Peter Brook famously quoted "I can take any empty space and call it a bare stage ... A man walks across this empty space while someone else is watching him, and this is all that is needed for an act of theatre to be engaged," 2 it is already a resonance of the philosophical concept of 'movement' which is at issue. To formally map out the relationship between philosophy and theatre through an analysis of the concept of 'movement' is beyond the scope of this paper. Nevertheless we would treat this relationship as the presupposed basis of this paper which would try to show how, not the Socratic, but another type of philosophical dialogues from antiquity-the Ciceronian dialogues-sets up this philosophical theatre through a particular way of externalizing the infinite internal dialectical movement of Socrates. Again, it is beyond the scope of this paper to follow an appropriate comparative analysis between the Socratic dialogues and the Ciceronian mimicking of them. Yet the paper would try to

\footnotetext{
${ }^{1}$ Soren Kierkegaard, The Concept of Irony with continual reference to Socrates, ed. and trans. by Howard V. Hong and Edna H. Hong (Princeton: Princeton University Press, 1989), 29.

2 Peter Brooks, The Empty Space (London: Penguin, 2008).
}

(c) 2015 Soumick De

http://www.kritike.org/journal/issue 17/de december2015.pdf

ISSN 1908-7330

$((c))$ BY-NC-ND 
present its argument with constant reference to Socrates, though in a much truncated and schematic fashion.

Thus, methodologically, the paper would be divided into three sections including certain concluding remarks. The first section would deal with the style and function of the Ciceronian dialogues (in reference to Socratic dialogues). The second section would present the nature of skeptic philosophy and the problem of externalization or mimicking within skeptic philosophy through an examination of the arguments in defence of this tradition, while the third and concluding section would try to very briefly counterpose the concept of Socratic daimon with that of Ciceronian persona.

\section{The Function and Style of Ciceronian Dialogues with Constant Reference to Socrates}

When Cicero retired from public life and decided to engage more openly with philosophy, in the latter part of his life, it is the dialogic method that he chose in order to express his philosophical concerns. The reason he gives for this choice has implications, which extend to the matters of the polis. The dialogic form was re-employed by Cicero as a response against what he thought was a growing dogmatism of the dominant schools of philosophy in his time, namely, the stoics and the epicureans. We find numerous references of this move against dogmatism in Cicero, a move which was not only embodied in the skeptic philosophy of the new academy and its dependence on a concept of probability (we shall return to this point) but also expressed through a form which would not harm those who hear it by making them obstinate followers of these camps or schools. The challenge was to find a method of pursuing philosophy, which would lead one to a state where he can be guided by his own reason in forming his own judgments. The exercise of philosophy as a matter of personal freedom of judgment was a fundamental principle of Ciceronian philosophy. And what better way to counter dogmatism that flourished on a stylistic use of positive statements (which in its turn produced a definite science of philosophy), than to revive the Socratic spirit of doubt. But now, the spirit of disputation would be brought back not only to counter dogmatism within philosophy but also to make philosophy accessible to the citizen subject. To make philosophy "the most useful means of educating (our) fellow-citizens." ${ }^{3}$ This pedagogic function of philosophy allied to the state was perhaps first fully expressed in Cicero because in Socrates, though there was certainly a pedagogic function to his philosophy, the tendency to ally it with the state was perhaps missing.

3 Cicero, De Natura Deorum \& Academica, trans. by H. Rackham (Cambridge, Massachusetts: Harvard University Press, 1933), 423.

(c) 2015 Soumick De

http://www.kritike.org/journal/issue 17/de december2015.pdf

ISSN 1908-7330

(c) BY-NC-ND 
Philosophy employed through the dialogic method could now be the perfect discursive technique, which could be concretely practiced by the citizen subject, thus making philosophy a useful tool for the republic. In the Nature of Gods, Cicero quite explicitly expresses his desire to philosophize as not only guided by the existential imperative of leading a truthful and virtuous life but also as a public service. He writes, "So my first thought was that I should explain philosophy to my fellow-citizens as a public duty, for I believed that the glory and reputation of the state would be greatly enhanced if such weighty and celebrated issues were discussed in Latin works as well as Greek." 4

But what happens to the Socratic method of doubting everything when applied to produce citizen-subjects, who can be made capable of exercising their freedom of judgment in order to appear in public? More specifically, how does the Socratic dialogue transform itself stylistically in the hands of Cicero to become a useful tool not only to educate but also to persuade individuals to follow certain principles, which would effectively provide them with the persona of the citizen?

Stylistically speaking, we observe in Cicero a complete change of situation for the dialogues as compared to Plato. While Plato gives the greatest importance to the date and place which establish a context in which the ensuing conversation is to be understood, in Cicero we have the leisurely retreat of the erstwhile statesman himself in either of his two gymnasia (one named the Academica, in honor of Plato and the other, Lyceum, in honor of Aristotle) or the home of a friend (like the home of Gaius Cotta, which serves as the backdrop for the dialogues in The Nature of the Gods), which keeps coming back as the location for these dialogues, while the time is mostly not specified or when it is-as in case of the First book of Academica-it is fictional. There is hardly any variation to the time and place of the dialogues in Cicero, which makes the situation effectively quite boring and repetitive. As Michael Foley correctly observes, "What is remarkable about the Platonic dialogues is the variety of their settings and situations: on a lonely road, at a drinking party, before a grand jury, etc. while Cicero also uses this technique his dialogues more often than not takes place at his Tusculan Villa in either of his two gymnasia." 5

If there were variations in the settings of Socratic dialogues, it was perhaps because-as Kierkegaard so brilliantly argues - for Socrates, the true centre was never fixed. The Socratic stage was always everywhere and nowhere. Socrates took any place and situation and made it into any other

\footnotetext{
${ }^{4}$ Cicero, The Nature of the Gods, trans. by P.G. Walsh (Oxford: Oxford University Press, 1997), 5-6.

${ }^{5}$ Michael P. Foley, "Cicero, Augustine and the Philosophical Roots of the Cassiciacum Dialogues" in Revue des Etudes Augustiniennes, 47 (1999), 55.

(c) 2015 Soumick De http://www.kritike.org/journal/issue 17/de december2015.pdf ISSN 1908-7330
}

(c) $\mathrm{BY}-\mathrm{NC}-\mathrm{ND}$ 
place and any other situation through a process of conversation, which essentially operated though a concept of irony. The Socratic art of asking questions was not to gain any profound answer which would give meaning and substance to a situation and thus speculatively move ahead to a resolution but to make all and every answer empty of its substance and every situation devoid of its meaning. As Kierkegaard writes, "This emphasis on situation was especially significant in order to indicate that the true centre for Socrates was not a fixed point but an ubique et nusquam (everywhere and nowhere) ... in order to make graphic the Socratic method, which found no phenomenon too humble a point of departure from which to work oneself up into the sphere of thought." 6 This hollowing out of the world stage made possible a veritable theatre of philosophy to take place through a movement which was infinitely carried out in its multiple and contingent forms but which always leads to the inevitable necessity of the negative. It is about this concept of negation epitomized by the Socratic slogan of knowing only and inevitably that one does not know that Kierkegaard informs us in his book The Concept of Irony with continual reference to Socrates. It is beyond the scope of this paper to engage in detail with the various movements of this irony, but suffice it to say here that the effect of such irony is to produce dialogue not in the form of merely contradictory speech, dialectically opposed to each other. In fact, as Kierkegaard goes on to show, the effect of irony through conversation - that is the technique of asking questions par excellence-was not speech at all. What such conversation necessarily leads to is silence. The interlocutor in participating in the conversation is slowly but inevitably caught in the trap, which Socrates lays out for him such that in the end he must become like Socrates-an ignorant and anonymous figure. The philosopher never achieves any superior position but conversely and ironically brings every superior position to his own level, which is that of ignorance and, hence, silence. This is the unexpected virtue of ignorance that every participant either realizes in order to become wise minimally ${ }^{7}$ or resents in prejudice. The Socratic movement thus begins from a "modest frugality" 8 of speech to the absence of speech altogether, achieved through conversation by the anonymous figure of the philosopher. This movement is completely and, if one might add, ironically absent in Cicero.

${ }^{6}$ Kierkegaard, The Concept of Irony, 16-17

${ }^{7}$ Here the idea of minimalism is not to be taken merely quantitatively as the measure of knowledge. The idea of frugality or minimalism that Kierkegaard informs us of in the philosophy of Socrates is rather a qualitative moment where although you have the least of knowledge which is your simple ability of not knowing, it paradoxically becomes the condition of possibility of maximum impact because it is on the basis of this minimum affirmation that the entire world of phenomenal knowledge is to be negated.

${ }^{8}$ Kierkegaard, The Concept of Irony, 18.

(c) 2015 Soumick De

http://www.kritike.org/journal/issue 17/de december2015.pdf

ISSN 1908-7330

(cc) BY-NC-ND 
What Cicero seeks through his dialogues is the abundance of speech as a private activity of the philosopher who in the leisure and comfort of his retreat wants not only to contemplate but also to educate and persuade the public to lead a life of virtue in conformity with the state. What we find in Ciceronian dialogues is, thus, the art of rhetoric substituting the art of questioning, while conversation is replaced by conference. The Tusculan Disputation is perhaps the best example of this philosophical conference where Cicero writes, "So it is my design not to lay aside my former study of oratory, and yet to employ myself at the same time in this greater and more fruitful art; for I have always thought that to be able to speak copiously and elegantly on the most important questions was the most perfect Philosophy." 9 Nothing could be farther from the Socratic sensibility of wisdom based upon ignorance and frugality, which resists the plenitude of oratory at every step.

It is not possible here to show the various other stylistic distinctions, which separate Cicero from Socrates. But one can already sense that there is a certain "pedestrianism," a certain utilitarian logic to Cicero which is missing in Socrates. The infinite and interior art of questioning in order to empty out existence, where the interlocutor not only participates externally in the act but also internalizes it in order to question his own self, is displaced or rather externalized into the art of question and answer which leads to speech and rhetoric in order to standardize a class of subjects who would now be prepared to participate in the affairs of the state wearing the mask of reason and virtue. The dialogue thus becomes a tool, the most useful and rational as far as philosophic methods are concerned, in order to paint the glorifying image of philosophy itself as the noblest and highest of all activities, the "most honorable delight of leisure."10 It is this persona of the philosopher as the figure of wisdom and, hence, superior to all that becomes the heart of the problem in Cicero, even if the wisdom is the suspension of all wisdom. Cicero remarks in Book I of Academica:

The method of discussion pursued by Socrates in almost all the dialogues so diversely and so fully recorded by his hearers is to affirm nothing himself but to refute others, to assert that he knows nothing except the fact of his own ignorance, and that he surpassed all other people in that they think they know things that they do not know but he himself thinks he knows nothing, and that he believed this to have been the reason why Apollo declared him to be the wisest of all men, because all

${ }^{9}$ Cicero, Tusculan Disputations, trans. by C.D. Yonge (New York: Harper \& Brothers Publishers, 1877), 5.

${ }^{10}$ Cicero, Academica, 413.

(c) 2015 Soumick De

http://www.kritike.org/journal/issue 17/de december2015.pdf

ISSN 1908-7330

(c) $)$ BY-NC-ND 
wisdom consists solely in not thinking that you know what you do not know. ${ }^{11}$

Whereas in Socrates, the absence of wisdom makes one wise minimally, which is what human wisdom amounts to ${ }^{12}$ in Cicero this fragile interiority of a realization which makes one wise has to be given a face, a personality quite distinct from others in its glory and superiority. In Socrates we have the expression of a personality, which in being the location of truth, is also and immediately the location of simulation because it exposes the emptiness of all faces, of all personalities - be it the orator, or the poet, or the craftsman. What Socrates shows, in hollowing out all faces, all personalities, is the human and finite predicament of having no knowledge, possessing no truth except the minimal knowledge of this negation. If we follow Kierkegaard's concept of irony as negation of the phenomenal world in Socrates, then what Socrates shows through such negation is perhaps this: that behind all appearance (be that of the orator or the poet, of Lycon or Meletus) is hidden nothing but the emptiness of all such appearance. ${ }^{13}$ It is not simply that the face of the poet or the craftsman hides some other truth about their existence. But in so far as they all fall into the same abyss of the emptiness behind their respective faces (which is also their mask), they bring into the phenomenal world nothing but their resemblance to each other, their simulations of each other, which include Socrates himself. This is the infinite

${ }^{11}$ Ibid., 425.

${ }^{12}$ In Apology, Socrates talks about human wisdom as against other kinds of wisdom, which is extra human. He, though ironically, talks of expert knowledge, particularly in the context of Evenus from Paros, who charges 500 drachmas for each of his sittings. Socrates claims to have no such expert knowledge about anything. For him, human knowledge amounts to nothing more that the minimal and limited access to one's own ignorance. And yet on the basis of this weak knowledge grounded on negation, he empties out all worldly forms of knowledge, dissolving them in metaphors, and makes an incommensurable 'leap' into the unknown. But all this happens within in the self with no help from the outside. See Plato "Apology" in Symposium and the Death of Socrates, trans. by Jane O' Grady (London: Wordsworth Classics, 1997), 83-115.

13 Giorgio Agamben, in his elegant little article called "The Face," discusses the problem of the face as the quintessential human urge to possess one's own appearance as the site of both knowledge and the struggle for truth. And yet this truth, according to him, this being manifest of appearance has nothing essential or substantive behind it but the act of manifestation itself. What the face brings into appearance is the very possibility of appearing. This is the truth of appearance, where all that remains behind the face is emptiness or a void, which is its eternal condition. The groundlessness of this ground, which is the face itself, has to be somehow displayed as having some substance, some meaning. This is the struggle for recognition, which Agamben equates with the act of taking possession or controlling of appearances. Whereas the appearance of the face can only in its simulation make manifest the possibility of appearance itself, the truth of such a universal possibility is turned into a personal recognizable truth when enacted through possession. See Giorgio Agamben "The Face," in Means without Ends: Notes on Politics, trans. by Vincenzo Binetti and Cesare Casarino, (Minneapolis and London: University of Minnesota Press, 1996), 91-100.

(c) 2015 Soumick De

http://www.kritike.org/journal/issue 17/de december2015.pdf

ISSN 1908-7330

(c) BY-NC-ND 
interior movement of the self caught in irony vis-à-vis the phenomenal world, which minimally realizes itself through this infinite interior dialectics.

In Cicero we find no such interiorization of truth, which leads to anonymity. What we find is the public display of this very subjective decision of acknowledging that one does not know but even this exposition is not done nakedly, never absolutely. (The nature of Ciceronian decision is that it has to be mediated or masked in order to make it more utilitarian. It is here, as we shall see in the following section, that the concept of probability comes in). The exposition thus transforms itself into a value in the name of the truth, which till now was infinite but accessible to all. The figure of the philosopher now comes into the public stage as the face, the persona who possesses the truth and who controls it. Thus, the finite personality of the philosopher in possessing truth gives it a value, which can now be distributed according to the order of the state and the hierarchy and status of personas. Thus, the elite erstwhile statesman possesses more wisdom than the statesman immersed in public life though he, in his turn, possesses more truth than the normal citizen and so on and so forth. This is the politics of the persona, which Cicero explains in the first book of De Officiis. ${ }^{14}$ But interestingly, by the same token of assigning a value to it, the infinite interiority of the Socratic truth is made finite, pedestrian. If in Socrates the task of the philosopher was to expose the truth in spite of himself, in which all, including the figure of the philosopher himself, would be anonymously dissolved, in Cicero the task of the philosopher seems to turn truth into "his own proper truth." 15 A value which when assigned to truth, which till now was free and accessible to all, is then accumulated in images, personas of different degrees and levels of truth accessible to each according to his persona but always jealously guarded by the highest of all personas, which is that of the philosopher. It is this externalization of an interior movement, to give a recognizable face to the

14 Stoic ethical doctrine from which, according to De Lacy, Cicero draws his concept of the persona in the first book of De Officiis, differentiates four conditions which need to be considered when we talk of personae: 1 . the nature we share with all human beings, 2 . our individual natures, 3. the persona arising from circumstances which is imposed onto us by chance and time, and 4 . those which pertain to our choices resulting from the judgment of the kind of life we wish to live. Although two of these conditions are supposedly natural to us, the duality of the concept of persona as both the face which we inhabit and the mask (the Greek residue of the idea of prosopon) which is external to us never loses its context. Hence, though all are human as different from god or animal, that individual is good who is always true to the role he plays no matter what the circumstances according to rational judgment and wisdom, which should always guide his choices. And since he cannot be truly wise, like Socrates, he cannot truly play the role of the wise man but can, nevertheless, try according to his natural capability try to be like Socrates. See Phillip H. De Lacy, "The Four Stoic 'Persona'” in Illinois Classical Studies, 2 (1977), 163-172.

${ }^{15}$ Agamben, "The Face," 97.

(C) 2015 Soumick De

http://www.kritike.org/journal/issue 17/de december2015.pdf

ISSN 1908-7330

(c) $)$ BY-NC-ND 
anonymous figure of the philosopher, which, we would argue, informs the nature of skeptic philosophy itself.

Two 'movements' are thus at work here in context of Ciceronian appropriation of Socratic dialogues.

1. An exteriorization and exposition of the Socratic interior movement of irony (through negation) in order to make such philosophical 'movement' useful for the state. This makes the Ciceronian 'movement' mimic the Socratic movement but also makes an infinite interior movement finite by assigning a value to it. This is the "pedestrianism" of Cicero, which this section has tried to argue.

2. In order to disseminate and make philosophy useful for the public, but still maintain the value of wisdom and truth ascribed to it in the name of negation of the phenomenal world, the concept of probability is devised which on one hand disseminates wisdom, but at the same time dissimulates it in order to retain the value ascribed to the persona of the philosopher who acknowledges his ignorance.

It is this second point that we shall try to briefly elaborate now in the second section.

\section{The Nature and Function of the Problem of Probability within Skeptic Philosophy}

In his book on epistemology, titled Academica, Cicero explains the problem of dogmatic knowledge, which informed the peculiar state of philosophy in his time. As Foley notes, "Cicero had competition: unlike Plato he had to contend with many well-developed and well-known schools of thought, some of them promoting themselves as the true heirs of the Socratic legacy."16 Academica is thus structured as a dialogue between the representatives of these 'decadent' forms of philosophy and his own conviction that it is only through the philosophy of the New Academy, which he championed that the classical model of Socrates and Plato could be saved. Here his main opponents were the stoics as represented by Varro and Lucullus in Book I and Book II, respectively.

$$
\text { Dialogues," 57-58. }
$$

16 Foley, "Cicero, Augustine and the Philosophical Roots of the Cassiciacum 
The Stoic School, presumably founded by Zeno, claimed to be a modification and not a rejection of the philosophy begun by Socrates. The fundamental critique of the skeptics against this school was in the domain of knowledge or logics, which then led to further criticism regarding physics and ethics, the two higher domains of philosophy in the classical world. This criticism came in view of the Stoic idea of sense perceptions or catalepsies. According to the changes made by Zeno in the domain of Logic, Cicero informs us, sensation was triggered by a combined operation of some sort of impact offered from outside which are received by the senses, termed phantasia (presentations) conjoined with the act of mental assent or syncatathesis, which he made out to reside within us and is thus a voluntary act. This process of reception and approval of the phenomenal world was jointly called catalepton or "mental grasp." It literally translates to the idea of grasping or gripping between the hands an object whose existence cannot be refuted. The question of assent is crucial here because in order for free presentations or phantasia to become 'manifestations' or truthful sensepresentations, they have to naturally offer themselves to approval or assent. Zeno further elaborates, again according to Cicero, that true things are naturally graspable, where the truth is inscribed or marked into the object. "They are recognized by a mark that belongs specially to what is true and is not common to the true and the false." 17 Here the relation between reason and catalepton is negative, where reason cannot remove the truth of what is naturally grasped and thus approved by the senses. It is against this idea of sense-presentation embodied in the idea of catalepton that Cicero forwards the concept of probability. The skeptic, Cicero asserts repeatedly, is not against the idea of truth. Rather the skeptic considers himself the most vigilant guardian of truth because he is guided by reason and not authority. And it is this reason, which asks him to doubt the nature of appearances as such both true and false. And since there is always the possibility that false sensations can appear exactly identical to true sensations; hence, all perception, which is based upon the inherent quality of a sensation which offers itself to approval, has to be rejected. And since no perception is possible, sense-presentations can be judged only partially, according to true reason, on the basis of their appearances. This leads 'the wise man to withhold assent' which the skeptics expressed through the doctrine of epoche. But to 'withhold assent' does not lead to inactivity and confusion of duty, which the stoics are accused of. Rather, according to Cicero, it leads to proper action without judgment being clouded by dogmatism. According to Cicero, the academics hold that there are dissimilarities between things, such that some of them seem probable while others their contrary. But this is not adequate ground for saying that

${ }^{17}$ Cicero, Academica, 511.

(c) 2015 Soumick De http://www.kritike.org/journal/issue 17/de december2015.pdf ISSN 1908-7330

(cc) BY-NC-ND 
some things can be absolutely perceived and others cannot, because many false objects are probable but nothing false can be perceived and known. Thus, Cicero writes:

The 'wise man withhold assent' is used in two ways, one when the meaning is that he gives absolute assent to no presentation at all, the other when he restrains himself from replying so as to convey approval or disapproval of something, with the consequence that he neither makes a negation nor an affirmation; and that this being so, he holds the one plan in theory, so that he never assents, but the other in practice, so that he is guided by probability, and whenever this confronts him or is wanting, he can answer 'yes' or 'no' accordingly. ${ }^{18}$

What such a distinction does to the concept of knowledge is to first and foremost de-radicalize the dialectical intensity of negation. This dilution of the intensity of negation still functions by opposing categories (probable and not probable), hence, mimics the infinite interior dialectic of Socratic dialogues but it is no longer able to produce a concept of irony which hollows out the phenomenal world through a conception of absolute negation. And hence, hierarchies are now established in the world of phenomenal knowledge, categories on the basis of which one can take finite decisions in the finite realm of appearances. Cicero writes, "Thus he is not afraid lest he may appear to throw everything into confusion and make everything uncertain." 19 But according to Socrates, it is exactly this uncertainty, which makes the philosopher wise because he can put anything and everything under his ironic vision, questioning and dismantling the established order of things within the state so that he can fulfill a higher duty outside the state, which is the private or subjective obligation to serve truth and justice. This distinction of the private from the public is crucial to Socrates whose teachings are always a private affair, ${ }^{20}$ a pedagogy which is not allied to the state. Thus, the Socratic sense of duty is different from the Ciceronian sense. Cicero further writes:

${ }^{18}$ Ibid., 601.

${ }^{19}$ Ibid., 609.

${ }^{20}$ In the context of Socrates, we should not confuse the idea of private and public in the modern sense of a distinction, which has juridical or even customary implication. Such a distinction could rather be compared with the Greek idea of the oikos and polis, the household and the city, which also resonates in the philosophy of Cicero and the Roman distinction of private and public. But in the Socratic sense, private is the interiority of the self as against the exteriority of the world and the movement from one to the other which, on the contrary, can take place anywhere, anytime, be in the oikos or the polis.

(c) 2015 Soumick De

http://www.kritike.org/journal/issue 17/de december2015.pdf

ISSN 1908-7330

(cc) BY-NC-ND 
For if a question is put to him about duty or about a number of other matters in which practice has made him an expert, he would not reply in the same way as he would if questioned as to whether the number of the stars is even or odd. And say that he did not know. For in things uncertain there is nothing probable, but in things where there is probability the wise man will not be at a loss either what to do or what to answer. ${ }^{21}$

Thus, the Ciceronian persona of the wise man is based on two fundamental principles - that in matters of public affairs that correspond to matters regarding the state, he will be dutiful according to the distribution of his senses, judging and affirming according to the demands of the phenomenal world. This is his public persona, which is immediately mediated by his modesty of not assenting to anything, of affirming that he does not know. This is what makes him wise because he now privately possesses the truth, which is the condition of possibility of all his worldly freedom of judgment. The theory of probability not only mediates this state of public practice of philosophy with the realm of private practice of theory but also gives a certain value to theory which makes it superior to practice. To dissimulate truth through a concept of probability is also to give truth the value it requires in order to have the scholastic status it requires in Roman society to become an effective political tool.

\section{Concluding Remarks}

The concept of irony sustained by a logic of negation, which informs the life of Socrates, comes as a gift of the absolute. (In "Apology," Socrates says he is gift to the state of Athens). Here the virtue of ignorance comes unexpectedly where the human participates in the divine, through establishing an absolute relation to the absolute. It is this relation, which is perhaps expressed in the Socratic idea of the daimon, a voice from within the self, which warns Socrates unexpectedly at different moments in his life. The daimon triggers decision in Socrates, which is neither completely divine, hence external to the self and imposed upon it, nor is it the human consciousness of his self mediated through reason. The daimon directs him minimally to enter upon a life of irony and negation by warning him unexpectedly of what not to do. It is not possible here to show an elaborate relationship between this unexpected daimonian gift and the knowledge of ignorance that Socrates possesses. Suffice it to say here that the constitutive inconsistency of the

${ }^{21}$ Cicero, Academica, 609.

(C) 2015 Soumick De

http://www.kritike.org/journal/issue 17/de december2015.pdf

ISSN 1908-7330

(c) $)$ BY-NC-ND 
affirmation that 'one only knows that one does not know' is related to the movement of the daimon, this secret movement of the self within itself. The un-decidability of knowing anything becomes the very condition for the possibility of the decision that 'one knows that one does not know' through the movement of this power of the self.

No such inter-subjective movement is available to Cicero. The inaugural decision of wisdom grounded on a 'constitutive inconsistency' is always put on hold through an act of dissimulation. Hence, in Cicero we find another kind of movement which is that of dissimulation, where a play of personas is determined by the mediation of truth through probability. Here by ascribing a value, truth is made useful for general purpose, which is embodied in the finite persona of the philosopher, thus making truth pedestrian. The skeptic argument of 'not even to know that one does not know,' which highlights the concept of probability, on the one hand dissimulates the inaugural inconsistency of Socratic negation by making it logically consistent. On the other hand, by de-radicalizing the movement of negation, it becomes successful in giving the anonymous figure of the philosopher a face.

Theatre and Performance Studies Department, School of Arts and Aesthetics Jawaharlal Nehru University, New Delhi, India

\section{References}

Agambem, Giorgio, Means without Ends: Notes on Politics, trans. by Vincenzo Binetti and Cesare Casarino (Minneapolis and London: University of Minnesota Press, 1996).

Brooks, Peter, The Empty Space (London: Penguin, 2008).

Cicero, De Natura Deorum \& Academica, trans. by H. Rackham (Cambridge, Massachusetts: Harvard University Press, 1993).

The Nature of the Gods, trans. by P.G. Walsh (Oxford: Oxford University Press, 1997). Tusculan Disputations, trans. by C.D. Yonge (New York: Harper \& Brothers Publishers, 1877).

De Lacy, Phillip L., “The Four Stoic 'Persona,'” in Illinois Classical Studies, 2 (1977). 


\section{CICERO AND THE "THEARTRICALITY" OF THE NEW ACADEMY}

Foley, Michael P., "Cicero, Augustine, and the Philosophical Roots of Cassiciacum Dialogues," in Revue des Etudes Augustiniennes, 47 (1999).

Kierkegaard, Soren, The Concept of Irony with Continual Reference to Socrates, ed. by and trans. by Howard V. Hong and Edna H. Hong (Princeton: Princeton University Press, 1989).

Plato, "Apology," in Symposium and the Death of Socrates, trans. by Jane O' Grady (London: Wordsworth Classics, 1997).

(C) 2015 Soumick De

http://www.kritike.org/journal/issue 17/de december2015.pdf

ISSN 1908-7330

(cc) BY-NC-ND 